\title{
Testing of Implant Prototype of Femoral Component Using Hydraulic Machine ZD40
}

Josef Sedlak, Martin Slany, Zdenek Fiala, Ales Jaros, Vendula Blazkova

Department of Machining Technology, Institute of Manufacturing Technology, Faculty of Mechanical Engineering, Brno University of Technology, Technická 2896/2, Brno 616 69, Czech Republic. E-mail: sedlak@fme.vutbr.cz, slany.m@fme.vutbr.cz, yfiala18@stud.fme.vutbr.cz,yjaros18@stud.fme.vutbr.cz, ysveco01@stud.fme.vutbr.cz

An article deals with a realization and a statistical evaluation of a pressure test using a hydraulic testing machine ZD 40 in order to determine a strength of a designed implant prototype of a femoral component, more precisely a maximal force $F$ that breaks a material and creates a crack. It is needed to make real testing samples of the new implant prototype of the femoral component for this purpose. Four pieces of testing samples are made in cooperation with the company in Velka Bites. Because of a price and availability in a range of offered cast materials testing samples are made of a bio tolerated cobalt alloy $\mathrm{Co}-\mathrm{Cr}-\mathrm{Mo}$ that is frequently implanted to a live organism. The implant prototype of the femoral component is designed from evaluated CT data of a patient's affected kneejoint (a femur distal part, a proximal tibia part). An individual 3D model of the implant prototype of the femoral component is created on the basis of editing of gained data in software CATIA.

The created 3D model is converted to *.stl format with a high resolution. Subsequently, the shell implant of the femoral component (a master model) is made using an additive method FDM (Fused Deposition Modelling). The next production method follows - production of a ceramic mould and casting of the real implant prototype of the femoral component from the bio tolerated cobalt alloy Co-Cr-Mo.

Keywords: Knee-Joint, Implant Prototype, Femoral Component, CATIA, Hydraulic Machine

\section{Acknowledgement}

The research was supported and co-financed from the project called "Excellent young scientists at VUT University in Brno"- register number CZ.1.07/2.3.00/30.0039.

\section{References}

[1] MAHONEY, O., MCClunG, C., PHIL, M., SCHMALZRIED, T. (1999). Improved Extensor Mechanism Function with the Scorpio Total Knee Replacement, Orthopaedic Research Society Annual meeting. Available at: http://www.stryker.com/orthopaedics/sites/scorpioknee/scorpiorefs.php.

[2] ValentINIn, J., R., Leyes, M. and Schweitzer, D. (1998). Spontaneous Osteonecrosis of the Knee. Treatment and Evolution. Journal Knee Surgery, Sports Traumatology, Arthroscopy. Volume 6, Number 1/January, pp. 112.

[3] Salai, M., Dudkiewicz, I., Blankstein, A., Israeli, A., Chechik, A. and Amit, Y. (2000). Bone Allograft in Revision Total Knee Replacement. Cell and Tissue Banking. Volume 1, Number 4/December, 2000, pp. 214.

[4] Rousseau, M., A., Lazennec, J., Y., and CatonnE, Y. (2005). Early Mechanical Failure in Total Knee Arthroplasty International Orthopaedics. International Orthopaedics 10.1007/s00264-006-0276-7, pp. 117.

[5] CHARVÁT, O., SEDLÁK, J., MADAJ, M. (2009). New Technique during Production of Knee Point Replacements. Strojírenská technologie, Vol. 2, No. XIV, p. 34-39. ISSN: 1211-4162.

[6] PÍŠKA, M., SEDLÁK, J., CHARVÁT, O., MADAJ, M. (2010). Kloubní implantát, zejména kolenního kloubu. Patent Owner: Brno University of Technology, Brno, CZ, pp. 5. Publisher: Industrial Property Office, Czech Republic. Document number: 21503. Document type U1. Registered: 29th November 2010.

[7] SEDLÁK, J. (2013). Moderní technologie výroby implantátu kolenního kloubu se specifickými požadavky na tvarové a funkční plochy: Habilitační práce. Brno: Brno University of Technology, Faculty of Mechanical Engineering, Department of Machining Technology, pp. 179, 9 appendices.

[8] SEDLÁK, J., CHARVÁT, O., MADAJ, M. (2011). Technology of processing CT data of the Knee Joint. Manufacturing technology, Vol. X, No. 1, p. 64-70. ISSN: 1213-2489.

[9] SEDLÁK, J., CHLADIL, J., SLANÝ, M., KOUŘIL, K. (2014). Introduction to Processing of CT Clinical Metadata of Disabled Part of Patient Knee Joint. Manufacturing technology, Vol. 14, No. 4, p. 611-618. ISSN: 12132489.

[10] Preparation and Evaluation of Material-graphic Samples - ASTM F75 (Co-Cr-Mo). [Online]. Brno: VUT University in Brno, Faculty of Mechanical Engineering, Institute of Material Science and Engineering, 2010. [Visited 15th December 2012]. Available at: http://ime.fme.vutbr.cz/files/Studijni\%20opory/PHMV/co_f75.php. 
[11] SEDLÁK, J. (2008). Technologie výroby prototypů s podporou reverzního inženýrství a CAD/CAM: Disertační práce. Brno: Brno University of Technology, Faculty of Mechanical Engineering, Department of Machining Technology, pp. 104, 11 appendices. Advisor of Dissertation Thesis doc. Ing. Miroslav PISKA, CSc.

[12] PROCHÁZKA. (2006). Modernization of Hydraulic Testing Machine ZD 40/400 KN [online]. [Visited. 26th May 2008]. Opava: TEMPOS, Opava, Czech Republic, October. Available at: http://www.tempos.cz.

[13] VYBÍRAL, B. Mechanics of Elastic Body. [Online]. [Visited 10th October 2012]. Available at: http://www.jaroska.cz/fo/_media/archiv/knihovna/pruznost_booklet.pdf.

[14] Static Pressure Test. [Online]. [Visited. 12th May 2012]. Available at: http://janhamernik.sweb.cz/Dilny/20032004/Lab15.htm.

[15] Meet Minitab 16: Pro Windows ${ }^{\circledR}$. [Online]. (C2006 Minitab Inc. All Rights Reserved, January 2007 [visited. 26th January 2013]. Available at: http://www.minitab.com.

[16] Anderson-Darling Normality Test. [Online]. [Visited 12th February 2013]. Available at: http://www.isixsigma.com/dictionary/anderson-darling-normality-test/.

[17] KARPÍŠEK, Z., POPELA, P., BEDNÁŘ, J. Statistics and Probability: Teaching Material: Studying Support for Combined Bachelor Study. Brno: CERM, 2002, pp. 89. Teaching Materials of Universities (VUT University in Brno. Faculty of Mechanical Engineering). ISBN 80-720-4261-0.

[18] LIKEŠ, J., LAGA, J. (1978). Basic Statistic Tables.1st publication. Prague: SNTL - Publisher of Technic Literature, n. p., pp. 564. ISBN 04-339-78. 